\title{
Intimate Partner Violence During Covid-19 Pandemic: Literature Review
}

\section{Covid-19 Pandemisi Sırasında Eş Şiddeti: Alanyazın Çalışması Zihniye Okray ${ }^{1}$, Cemaliye Direktör ${ }^{2}$ Güley Bilgi Abatay ${ }^{3}$}

\begin{abstract}
:
With the COVID-19 pandemic, staying at home, social isolation and many protection measures that will prevent the transmission of the virus have been implemented by the states with regard to the recommendations of the World Health Organization. Although such social isolation decisions prevent the community transmission of the COVID-19 pandemic, they also brought others together. While the houses are seen as a safe place to protect against the virus, there has been a pandemic of violence against women in the home. Since the decisions of social isolation, applications and emergency calls regarding intimate partner violence have increased and women have been exposed to violence more frequently and more seriously than before the pandemic. This study differentiates factors that show co-growth of intimate partner violence in psychosocial crises such as pandemics. The research shows that spousal violence occurs throughout societies regardless of socio-economic and educational status, long-term sharing of homestay and economic losses caused by the pandemic are important variables that increase spousal violence.
\end{abstract}

Keywords: COVID-19, pandemic, intimate partner violence, triggers

\footnotetext{
${ }^{1}$ Assoc. Prof., European University of Lefke, Faculty of Arts and Science, Department of Psychology, Lefke, Cyprus, Orcid: 0000-0002-9117-4991.

${ }^{2}$ Assist. Prof., European University of Lefke, Faculty of Arts and Science, Department of Psychology, Lefke, Cyprus, Orcid: 0000-0002-6055-2224

${ }^{3}$ Assist. Prof., Final University, Faculty of Education, Psychological Counseling and Guidance Department, Kyrenia, Cyprus, Orcid: 0000-0003-4814-2107

Address of Correspondence/Yazışma Adresi: European University of Lefke, Faculty of Arts and Science, Department of Psychology, Lefke, Cyprus, E-mail: zokray@eul.edu.tr

Date of Received/Geliş Tarihi: 27.07.2021, Date of Revision/Düzeltme Tarihi: 05.10.2021, Date of Acceptance/Kabul Tarihi: 21.10.2021, Date of Online Publication/Çevirimiçi Yayın Tarihi: 01.12.2021

Citing/Referans Gösterimi: Okyay, Z., Direktör, C. \& Abatay, B. G. (2021). Intimate Partner Violence During Covid-19 Pandemic: Literature Review, Cyprus Turkish Journal of Psychiatry \& Psychology, 3(4): 289-297

(C) 2021 The Author(s). Published by Cyprus Mental Health Institute / Cyprus Turkish Journal of Psychiatry and Psychology (www.ktppdergisi.com). This article is an open access article distributed under the terms and conditions of the Creative Commons Attribution 4.0 license which permits use, sharing, adaptation, distribution and reproduction in any medium or format, provided the original work is properly cited and is not used for commercial purposes. http://creativecommons.org/licenses/by/4.0/
} 


\section{Öz:}

COVID-19 pandemisi ile birlikte evde kalma, sosyal izolasyon ve bunun gibi virüsün bulaşını engelleyecek bir çok önlem Dünya Sağlık Örgütü tavsiyeleri doğrultusunda devletler tarafından alınmış ve uygulamaya konulmuştur. Bu gibi sosyal izolasyon kararları COVID-19 pandemisinin toplum içerisinde bulaşını engellese de beraberinde başka sorunları da getirmiştir. Evler virüsten korunmak için güvenli bölgeler olarak görülürken ev içinde kadına yönelik şiddet pandemisi ortaya çıkmıştır. Sosyal izolasyon kararlarının alınmasından itibaren eş şiddeti ile ilgili başvurular artmış ve kadınlar pandemi öncesinden daha sık ve daha ciddi boyutlarda eş şiddetine maruz kalmışlardır. Bu çalışmanın amacı pandemi gibi psikososyal krizlerde eş şiddetini artıran faktörleri tespit etmektir. Araştırma sonucunda eş şiddetinin dünya genelinde sosyo-ekonomik ve eğitim durumu gözetmeksizin toplumların genelinde yaygın şekilde ortaya çıktığı, aile üyelerinin uzun süreler aynı ortamı paylaşması ve pandeminin yarattığı ekonomik kayıpların eş şiddetini artıran önemli değişkenler olduğu görülmüştür.

Anahtar Kelimeler: COVID-19, pandemi, eş şiddeti, tetikleyiciler

\section{Giriş}

Çin'in Wuhan kentinde ortaya çıkan ve tüm dünyayı saran yeni tip koronavirüs (COVID-19), Dünya Sağllk Örgütü (WHO) tarafından halk sağlı̆̆ını tehdit eden bir salgın olarak ilan edilmiştir (WHO, 2020). WHO'nun 11 Mart 2020'de (WHO, 2020) COVID-19 salgınını bir pandemi olarak nitelendiren açıklamasından sonra, dünyanın dört bir yanındaki hükümetler ve yetkililer, virüsün yayılmasını azaltmak ve kontrol altına almak için ülke sınırları kapatılmış veya girişler sınırlandırmış; aynı zamanda sosyal mesafe tedbirlerini uygulamaya konulmuştur (Hall ve Tucker, 2020). Bu doğrultuda 142 ülkede kapanma tedbirlerinin uygulandığ 1 bilinmektedir (Hale, Webster, Petherick, Phillips ve Kira, 2020). Büyük pandemik veya epidemik salgınların bireyler ve toplum üzerinde birçok olumsuz etkisinin olması beklenmektedir. Özellikle gelişmekte olan ülkelerde toplumsal cinsiyet eşitsizliğine bağlı olarak kadınların daha çok olumsuzluğa maruz kalacağına dair endişeler artmaktadır. Geçmiş salgınlardan elde edilen bilgiler özellikle eş şiddetinin arttığını göstermektedir (Roesch, Amin, Gupta ve Garcia-Moreno, 2020). Mohler ve arkadaşları (2020) önceki salgınlardaki gibi COVID-19 salgını sırasında da aile içi şiddet raporlarının arttığını belirtmektedirler. Benzer şekilde Bradbury-Jones ve Isham (2020) da kapanma, evde kalmaya zorlanma gibi izolasyonların aile içi şiddet ve istismar olgularını artırdığını bildirmişlerdir. Aile içi şiddetin bir parçası olan eş şiddetinin de salgınlar da dahil olmak üzere acil durumlarda artma eğiliminde olduğu belirtilmektedir (Boserup, McKenney, ve Elkbuli, 2020; Bradley, DiPasquale, Dillabough ve Schneider, 2020). Şiddet olgularında sosyoekonomik düzey önemli bir faktör olmaktadır. Kapanmaya bağlı olarak evde kalan aile bireylerinin yeterli kişisel alana sahip olamaması ve yakın olmaya zorlanmaları, eş şiddetini olduğundan daha olumsuz hale getirmektedir (Brown, Ravallion ve Van De Walle, 2020). Ergönen, Biçen ve Ersoy (2020) Türkiye'de kadına yönelik şiddetin bir önceki yıla göre COVID-19 sonrasında psikolojik şiddetin \%93, fiziksel şiddetin ise $\% 80$ oranında arttığını belirtmektedirler. Avustralya, Brezilya, Çin ve Amerika Birleşik Devletleri'nden gelen son anekdot raporları, karantina nedeniyle eş şiddetinde artış olduğunu göstermektedir (Peterman, Potts, O'Donnell, Thompson, Shah, OerteltPrigione ve van Gelder, 2020). New Orleans'da yapilan bir çalışmada pandemi öncesinde eş şiddetine maruz kalanların \%59'u şiddetin COVID-19 sonrası arttı̆̆ını ifade etmişlerdir (Buttel ve Ferreira, 2020). Sosyal mesafe, izolasyonu sağlarken erișilebilir destek seçeneklerini kısıtlayarak bireysel ve toplumsal güvenlik açıklarının oluşmasına zemin hazırlamaktadır (Van Gelder ve diğ., 2020). Bu güvenlik açığı potansiyel eş şiddetinin artması ile sonuçlanmaktadır. Eş şiddeti eski veya mevcut yakın duygusal ilişki içerisinde bireyler arasinda meydana gelen fiziksel, psikolojik, duygusal, ekonomik veya cinsel şiddet olarak tanımlanmaktadır (Miller ve McCaw, 2019). Tipik olarak her yaştan kadın tarafindan görülmekte ve kadınlar için cinayetten ölümlerin önde gelen nedenini temsil etmektedir. Daha düşük şiddette erkeklerin yaklaşık üçte birinde de eş şiddeti yaşanabilmektedir (El-Serag ve Thurston, 2020). Genel olarak aile içi şiddete maruz kalma, bir bireyin gelecekteki ilişkilerinde şiddet uygulama veya başka zararlı zihinsel ve davranışsal sağlık sonuçları geliştirme riskini artırmaktadır (Ingram ve diğ. 2020). Eş şiddeti, dünya çapında ciddi, oldukça yaygın ve önlenebilir bir halk sağlığı sorununu temsil etmektedir. Alan yazın incelendiğinde, hangi faktörlerin bir kişinin istismarın kurbanı olarak şiddet içeren bir ilişkinin parçası olmasına neden olabileceğini tartışmaktadır, gelinen ortak noktada ise şiddetin nedeninin birey, ilişki, topluluk ve toplumsal faktörlerin bir kombinasyonu olarak açıklanmaktadır (Miller ve McCaw, 2019). Kapanma sirasında istihdam durumunun değişmesi nedeniyle tehlikeye giren düşük veya yetersiz gelir, şiddetin tetiklenebileceği bir ortam olan aile stresine, hayal kırıklıklarına ve yetersizliğe katk1da bulunabilmektedir (Barnawi, 2017). Bu stres, hayal kırıklığ psikopatolojik sorunları şiddetlendirebilir ve şiddet olaylarını daha da hızlandırabilmektedir (Gulati ve Kelly, 2020; Telles, Valenca, Barros ve da Silva, 2020).

Şiddet içeren bir ilişkinin dinamiklerini ve eş şiddeti ile ilişkili faktörleri anlayarak, COVID-19'un bu faktörleri nasıl şiddetlendirerek şiddetin artmasına ve hatta yeni tür taciz davranışına yol açabileceğini anlamak mümkün olmaktadır. Siddete ek olarak, Covid19 yayılımını azaltmak için uygulanan sosyal önlemler mağdurların psikolojik sağlık durumlarını etkileyebilmektedir. Sosyal izolasyon, yardım alma mekanizmalarının sağlıklı çalışmasına engel olarak şiddet mağdurlarının yardım almasına engel olabilmektedir. Ev içerisinde olma, fail ile daha fazla vakit geçirme zorunluluğunu beraberinde getirirken bir yandan şiddeti artırmakta, diğer yandan da 
koruyucu hizmetlere ulaşımı güçleştirmektedir (Altın, 2021). COVID-19 tüm bireylerin hayatlarını kökten değiştirmiştir. Kapanma ve karantina sırasında ev, aile içi şiddet mağdurları için çok tehlikeli bir yer olma riskini taşımaktadır. Kepenek (2021) raporlarına göre 2020 yılı içerisinde Türkiye'de 284 kadın öldürüldü. Öldürülen kadınların \%65'i koca/sevgili, \%19 aile üyesi, \%7'si tanıdık ve \%2'si de tanımadıkları kişi tarafından öldürülürken bu ölüm olaylarının \%'7'si de basına yansımamıştır. Öldürülme eylemlerinin $\% 48$ 'i ev içinde gerçekleşmiştir. 2020 yılı içerisinde ev içi şiddet olgularındaki artışlar farklı araştırmalarla şu şekilde ifade edilmiştir. Çin'de geçtiğimiz yıla göre \%90, Fransa'da \%30-36, Brezilya'da \%40-50, Arjantin'de \%25, Singapur'da \%33, ABD'nin farklı eyaletlerinde ise \%1035 arasında artış göstermiştir (John, Casey, Carino ve McGovern, 2020, Toprak Ergönen, Biçen, Ersoy, 2020). $\mathrm{Bu}$ oranların yanı sira Bradbury- Jones ve Isham, (2020) göre sosyal izolasyon ve kapanma kararının alınmasından itibaren aile içi şiddet yardım hatlarının aranma oranları İngiltere'de \%25, İspanya'da \%20 ve Güney Kıbris'ta da $\% 30$ oranında artsş göstermiştir. Sanchez, Vale, Rodrigues ve Surita (2020) COVID-19 pandemisine yanıt olarak kabul edilen sosyal mesafe tedbirleri bağlamında kadına yönelik aile içi şiddetle mücadele stratejileri ve önerileri üzerine çalışmaların yapılmasının önemine vurgu yapmaktadırlar. Buna bağlı olarak bu çalışmada kadına yönelik şiddette COVID-19 süreci boyunca alan yazında yer alan eş şiddetinin sistematik derleme ile incelenmesi amaçlanmaktadır.

\section{Yöntem}

$\mathrm{Bu}$ çalışma sistematik bir inceleme olup Scopus ve ScienceDirect veri tabanlarında 2020-2021 yılı içerisinde yayınlanmış makaleleri içermektedir. Sistematik derleme, klinik bir soruya yanıt ya da probleme çözüm oluşturmak için, o alanda yayınlanmış tüm çalışmaların kapsamlı bir biçimde taranarak, çeşitli dâhil etme ve dışlama kriterleri kullanarak ve araştırmaların kalitesi değerlendirilerek hangi çalışmaların derlemeye alınacağının belirlenmesi, derlemeye dâhil edilen araştırmalarda yer alan bulguların sentez edilmesidir (Karaçam,2013). Ocak 2021 tarihinde Scopus ve ScienceDirect veri tabanlar1 " 'COVID-19' AND 'intimate partner violence' " anahtar kelimeleri ile taranmıştır. Taramada dil kısıtlamasına gidilmemiştir. Yapılan bu ilk tarama sirasında Scopus veri tabanında 60, ScienceDirect veri tabanında 60 makale bulunmuştur. $\mathrm{Bu}$ ilk tespitin ardından bazı ekleme ve dışlama ölçütlerine dayanarak bu çalıșmanın temel veri kaynaklarına ulaşılmıştır.
Ekleme ve dişlama ölçütlerinde uygulanan basamaklar aşağıdaki gibidir:

Adım 1. Makalenin 2020 ve sonrasında yayımlanmış olmas1

Adım 2. Makalenin başlık, anahtar kelime ve özetinde 'Covid19' ve 'intimate partner violence' ifadelerinin bulunmas1

Adım 3. Derleme ve Editöre Mektup niteliğinde olan makalelerin elenmesi.

Adım 4. Çocuk ve yaşlılara yönelik aile içi şiddet çalışmalarının elenmesi

Adım 5. Birden fazla veri tabanında ortak olarak taranmış olan araştırma makalelerinin elenmesi.

$\mathrm{Bu}$ ekleme ve dışlama ölçütlerine göre Scopus veri tabanında ölçütlere uygun 12 , ScienceDirect veri tabanında ölçütlere uygun 4 toplamda 16 araştırma makalesi çalışmaya dâhil edilmiştir.

\section{Bulgular}

Agüero (2020) Peru'da aile içi şiddet yardım hattı olan Linea 100 yardım hattına COVID-19 pandemisi ve evde kal çağrıları yapıldıktan sonra yapılan başvuruların sıklığını değerlendirmiştir. Yapılan bu çalışmaya göre Nisan-Temmuz 2020 tarihleri arasında Linea 100'e yapılan çağrılar bir önceki yıl aynı dönemle kıyaslandığında \%48'lik bir artış göstermiş̧tir. Araştırmacılar başvuranların sosyo-demografik özelliklerini incelediklerinde ise şiddet olgularının düşük ya da yüksek sosyo-ekonomik düzeyler arasında farklılık göstermediğini ve toplumun genelinde yaygınlık kazandığını tespit etmişlerdir.

Baig, Ali ve Tunio (2020) Pakistan'da var olan ataerkil yapının kadına yönelik şiddet konusunun konuşulmasının bile tabu olarak değerlendirildiğini ve bu yüzden kadına yönelik şiddet konusunda önlem alma çabalarının bile neredeyse imkânsız olduğunu vurgulamışlardır. Sadece Mart 2020 tarihinde 399 kadın eşleri tarafindan evlerinde öldürülmüs ve bu dönemde aile içi șiddet konusunda polise sadece 25 başvuru yapılmıştır. Araştırmacılar Pakistan'da toplumun bilinçlendirilmesi, kadına yönelik şiddet konusunda ceza yaptırımlarının getirilmesi ve COVID-19 döneminin tele-tıp ve benzeri uygulamalarla Pakistan için bir dönüm noktası olabileceğini vurgulamışlardır.

Tablo 1. Araştırmada İncelenen Çalıșmaların Genel Özellikleri

\begin{tabular}{|c|c|c|c|c|}
\hline Yazar & Konu & Örneklem & $\begin{array}{l}\text { Veri Toplama } \\
\text { Yöntemi }\end{array}$ & Sonuç \\
\hline $\begin{array}{l}\text { Agüero J. M. } \\
(2021) \text {. }\end{array}$ & $\begin{array}{l}\text { Peru'da bulunan } \\
\text { Linea } 100 \text { yardım } \\
\text { hattına yapılan } \\
\text { çağrıların sıklığ }\end{array}$ & $\begin{array}{l}\text { Nisan- } \\
\text { Temmuz } \\
2020 \\
\text { arasındaki } \\
\text { çağrılar }\end{array}$ & Nicel çalışma & $\begin{array}{l}\text { COVID-19 pandemisi ve } \\
\text { karantina ve sosyal izolasyon } \\
\text { koşulları altında toplumun } \\
\text { genelinde eş şiddetinde \% } \% 8^{\prime} \text { 'lik } \\
\text { bir artış tespit etmişlerdir. }\end{array}$ \\
\hline $\begin{array}{l}\text { Baig, M. A. } \\
\text { M., Ali, S., \& } \\
\text { Tunio, N. A. } \\
(2020) .\end{array}$ & $\begin{array}{l}\text { Pakistan'da COVID- } \\
19 \text { pandemisi } \\
\text { sirasında kadına } \\
\text { yönelik şiddet }\end{array}$ & $\begin{array}{l}\text { Mart } 2020 \\
399 \text { kadın } \\
\text { eşleri } \\
\text { tarafindan } \\
\text { öldürülmüstür }\end{array}$ & Nitel çalışma & $\begin{array}{l}\text { Mart } 2020 \text { 'de } 399 \text { kadın eşleri } \\
\text { tarafından öldürülmüş ve sadece } \\
25 \text { polis çağrısı yapılmıştır. } \\
\text { Araştırmacılar ataerkil bir yapıya } \\
\text { sahip Pakistan'ın kadına yönelik }\end{array}$ \\
\hline
\end{tabular}


Ertan, D., El-Hage, W., Thierrée, S., artışına bağlı Javelot, H. \& koruyucu uzun vadeli Hingray, C. önlemlerin alınması (2020).

$\begin{array}{ll}\text { Gebrewahd, } & \text { Doğurganlık } \\ \text { G.T., } & \text { çağındaki kadınların } \\ \text { Gebremeskel, } & \text { COVID-19 sürecinde } \\ \text { G.G. \& } & \text { maruz kaldıkları } \\ \text { Tadesse, } & \text { şiddet } \\ \text { D.B.(2020) } & \\ \text { Ghimire, C., } & \text { Nepal'de COVID-19 } \\ \text { Acharya, S., } & \text { sürecinde şiddetin } \\ \text { Shrestha, C., } & \text { sıklığının araştırılması } \\ \text { KC, P., } & \\ \text { Singh, S., \& } & \\ \text { Sharma, P. } & \\ \text { (2020). } & \\ & \\ \text { Gulati, G., \& } & \text { COVID-19 pandemisi } \\ \text { Kelly, B. D. } & \text { kadına yönelik şiddet } \\ \text { (2020). } & \text { ve psikiyatrinin } \\ & \text { rolünü } \\ \text { Hsu, L.C., } & \text { incelemişlerdir. } \\ \text { COVID-19, evde kal } \\ \text { A.(2020). } & \text { ve aile içi şiddet } \\ & \text { ilişkisi }\end{array}$

Leslie, E., \& COVID-19 pandemisi Wilson, R. (2020).

Matoori, S.,

Khurana, B. Balcom, M.C. et al.(2020). Mazza, M., Marano, G., Lai, C. Janiri, L., \& Sani, G. (2020). Moreira, D. N., \& Pinto da Costa, M. (2020).

Sharma, A., Borah, artıran faktörlerin Dünya çapında aile içi şiddet olgularının sirasında şiddet olgularının artışı

Alanyazın çalışması ve öneriler

$\mathrm{n}=682$

$n=556$

Alanyazın çalışması ve öneriler

ABD'de 35 şehir ve bir ilçedeki polis başvuruları ve olgular ABD'de 14 metropol şehirde polise yapilan çağrılar

\section{Radyoloji} uzmanları sirası ve sonrasında es şiddetinde radyoloji uzmanları nasıl bir fark yaratabilir? COVID-19 pandemisi sırasında kişiler arası şiddeti

COVID-19 pandemisi sırasında eş şiddetini incelenmesi

COVID-19 pandemisi ve aile içi şiddetin

Medline,

Scopus ve Embase veri tabanlarının taranması tapanının taranmas1 kuruluşlarla
Nitel çalışma

şiddeti bir tabu olarak görülmesinin önüne geçilmesinin tele-tıp yolu ile olabileceğini tartışmışlardır.

Devlet ve sivil toplum kuruluşlarının birlikte çalışması, 7/24 esasına dayalı yardım hatları geliştirilmesi, sosyal çevrenin desteğinin sağlanması ve devletin kurbanlara sosyal ve ekonomik güvence verilmesi.

Kesitsel çalışma Kadınların eş şiddetine maruz kalma oranı \%24.6 olarak tespit edilmiştir. \%13.3 psikolojik şiddet, $\% 8.3$ fiziksel şiddet ve $\% 5.3$ 'de cinsel şiddete maruz kalmışlardır.

Kesitsel çalışma Araştırmaya katılanların $\% 18^{\prime} i(n=100) \quad$ pandemi ve kapanmalar sırasında ayni evi paylaştıkları eşleri tarafından şiddete maruz kalmışlardır. Alkol ve sigara tüketimleri artmış ve DSÖ iyilik indeksine göre daha düşük puanlar almışlardır.

Nitel çalışma Madde bağımlılığı ve eş tanılı akıl hastalıkları hem fail hem de kurban olarak eş şiddetinin riskini artırmaktadır.

Eş şiddeti olgularının \%5.3 oranında arttığını tespit etmişleridir.

İlk beş haftada aile içi şiddet olgularında \%7.5'lik bir artış görülmüştür. Herhangi bir demografik değişkene bağlı olarak değil genel popülasyonda şiddet artmıştır.

Radyoloji uzmanlarına eş

Tomografi sonuçları ve acil servis görüşmeleri

PubMed/ Nitel çalışma

PubMed veri Nitel çalıșma

Yardım veren Nitel çalışma şiddetini belirleme ve atılması gereken adımlar konusunda rehber geliştirilmiştir.

Pandeminin yarattığ kırıklığı ve ajitasyon duygularının kuşaklar arasında travma ve şiddet olarak aktarıldığ $\quad$ sonucuna varmışlardır.

COVID-19 pandemisi bireysel, ilişkisel ve toplumsal/sosyal risk faktörlerini beraberinde getirmiş ve eş şiddetinin sıklığı ve şiddeti artmıştır.

Eş şiddetinin s1klığ 1 ve şiddeti artmıştır ve buna en önemli 


\begin{tabular}{|c|c|c|c|}
\hline S.B.(2020). & $\begin{array}{l}\text { sosyal ve ekonomik } \\
\text { krizdeki dolaylı yol } \\
\text { oluşturması. }\end{array}$ & görüşme & \\
\hline $\begin{array}{l}\text { Bright, C.F., } \\
\text { Burton, C. \& } \\
\text { Kosky, M. } \\
(2020) .\end{array}$ & $\begin{array}{l}\text { COVID-19 pandemisi } \\
\text { sırasında yaşanan } \\
\text { kapanmanın ilk } 6 \\
\text { haftasında yayınlanan } \\
\text { aile içi şiddet } \\
\text { haberlerinin } \\
\text { incelenmesi }\end{array}$ & $\begin{array}{l}300 \text { haber } \\
\text { yazisı }\end{array}$ & Nitel çalışma \\
\hline $\begin{array}{l}\text { Hamadani, } \\
\text { J.D., Hasan, } \\
\text { M.I., Baldi, } \\
\text { A.J., Hossain, } \\
\text { S.J., Shiraji, } \\
\text { S., Bhuiyan, } \\
\text { M.S.A., } \\
\text { Fisher, J., } \\
\text { Tofail, F., } \\
\text { Tipu, } \\
\text { S.M.M.U., } \\
\text { Grantham- } \\
\text { McGregor, } \\
\text { S., Biggs, } \\
\text { B.A., Braat, } \\
\text { S. \& } \\
\text { Pasricha, } \\
\text { S.R. (2020). }\end{array}$ & $\begin{array}{l}\text { Bangladeş } \\
\text { kırsalındaki kadın ve } \\
\text { ailelerin COVID-19 } \\
\text { pandemisinden } \\
\text { etkilenme } \\
\text { durumlarının } \\
\text { incelenmesi }\end{array}$ & $\mathrm{n}=2424$ & Kesitsel çalışn \\
\hline $\begin{array}{l}\text { Arenas- } \\
\text { Arroyo, E., } \\
\text { Fernandez- } \\
\text { Kranz, D. \& } \\
\text { Nollenberger, } \\
\text { N. (2021). }\end{array}$ & $\begin{array}{l}\text { COVID-19 pandemisi } \\
\text { sirasinda zorla birlikte } \\
\text { yaşama ve ekonomik } \\
\text { stresin eş şiddeti } \\
\text { üzerindeki etkisini } \\
\text { belirleme }\end{array}$ & $\mathrm{n}=13786$ & Nicel çalışma \\
\hline
\end{tabular}

Vieroa, A., $\quad$ Kadına yönelik şiddet Barbarab, G., ～ve COVID-19 salgını Montiscia, M., arasındaki ilişki hakkındaki

Kustermannc, alanyazının hızlı ve K. \& eleştirel bir incelemesi
Alanyazın Nitel çalıșma çalışması ve öneriler etkenler iş kaybı, ekonomik kayıplar ve aynı ev içinde daha uzun süreler kalmak neden olmuştur.

Araştırmanın sunulan ön verilerine göre sosyal izolasyon ve kapanmasının yarattı $\breve{g} 1$ stres ile aile içi şiddettin arttı $\breve{1}$ belirtilmiştir.

Eşleriyle birlikte yaşayan 2174 kadın, kapanma sırasında eş şiddetine maruz kalmıştır. Buna ek olarak kapanma sonrasinda duygusal şiddettin \%68.4, fiziksel şiddettin $\% 56$ ve cinsel şiddettin ise $\% 50.8$ arttı̆ 1 bildirilmiştir.

Cattaneo, C.

(2020).

Gebrewahd, Gebremeskel ve Tadesse (2020) Etopya'da doğurganlık çağında olan 682 kadına anket uygulamışlardır. Elde ettikleri bulgulara göre kadınların COVID-19 pandemisi sırasında 524.6 oranında şiddete maruz kaldıkları, \%13.3'ünün psikolojik, \%8.3'ünün fiziksel ve \%5.3'ünün de cinsel şiddete uğradıkları görülmüştür. Kadınların yaşları küçük (30 yaştan küçük), eğitim durumları düşük ve evlilikleri de ayarlanmış ( görücü usulü) evlilikler ise şiddete maruz kalma risklerinin arttığını istatistiksel analizlerle tespit etmişlerdir.
Ghimire, Acharya, Shrestha, Singh ve Sharma (2020) Nepal'de Dünya Sağlık Örgütü (DSÖ) iyilik indeksini 556 katılımcıya çevrim içi olarak uygulamıştır. Alınan sonuçlara göre kadınların \%18'i( $\mathrm{N}=100)$ pandemi ve kapanma sırasında eşleri tarafından şiddete maruz kalmışlardır. Hem kurbanların hem de faillerin bu dönemde alkol ve sigara kullanma sıklıkları artmış ve DSÖ iyilik indeksinden daha düşük puanlar almışlardır. Bu çalışmada yaşları daha küçük ve eğitim düzeyi daha düşük olan katılımcıların şiddet kurbanı oldukları tespit edilmiştir. Eşleri ile yalnız yaşayanların şiddete uğrama 
riskleri \%37.5 olarak tespit edilmiștir. En s1k rastlanan istismar türü sözel ve fiziksel şiddet olmuștur. Bu örneklem grubunda daha önceden sahip olunan bir ak1l hastalığ değişken olarak tespit edilmiştir.

Gulati ve Kelly (2020) COVID-19 pandemisi sırasında psikiyatri servislerine ve orada çalışanlara büyük görevler düştügünü belirtmişlerdir. Bu süreçte araştırmacılar akıl hastalığına sahip hem fail hem de kurban olabileceklerini dile getirmişlerdir. Özellikle madde kullanım bozukluklarının yanı sıra sahip olunan akıl hastalıklarının eş şiddetine karşı bir risk faktörü olduğunu vurgulamışlardır. Diğer taraftan akıl hastalığına sahip bireylerin aile içi şiddet ve eş şiddetinin kurbanı olma risklerini de arttırdığını ifade etmişlerdir.

Hsu ve Henke (2020) Amerika Birleşik Devletleri'ndeki (ABD) 35 şehir ve bir ilçede polise eş şiddeti nedeni ile başvuran olguları değerlendirmişleridir. Yaptıkları çalışma sonucunda COVID-19 pandemisi ve evde kalma / karantina süreci başladıktan sonra eş şiddeti olgularında \%5.3'lük bir artış tespit etmişlerdir. Araştırmacılar eş şiddetindeki bu artışı kurban ve failin sokağa çıkma kısıtlamalarından dolayı aynı evin içine sıkışıp kalmalarından dolayı gerçekleştiğini vurgulamışlardır.

Ertan, El-Hage, Thierrée, Javelot ve Hingray (2020) dünya çapında COVID-19 pandemisi ve alınan önlemler doğrultusunda aile içi şiddet fakat özellikle eş şiddeti ve çocuk istismarı olgularında büyük bir artış olduğunu dile getirmişleridir. $\mathrm{Bu}$ dönemde uzun dönem önleme programlarının geliştirilmesi gerekliliğini vurgulamıșlardır. Calıșmalarında es şiddetinin sıklığının ve şiddetinin aratmasında önemli etkenler arasında bulaşın önlenmesi için alınan evde kalma, sosyal izolasyon gibi önlemlerin kurbanlar için yüksek risk içeren bir ortam yarattığını, pandeminin getirdiği psikososyal stresörlerin şiddet içeren davranışları artırdığını ve kurbanların koruyucu önlemler ulaşmasını engellemesinin neden olduğunu vurgulamışlardır. Alınmas1 gereken önlemlerde ise devletin kurbanlara sosyal ve ekonomik güvence sağlamasının yanı sıra sivil toplum kuruluşları ile işbirliği içerisinde kurbanlara geçici ya da kalıcı güvenli evler sağlamaları ve yedi gün yirmi dört saat esası ile çalışacak yardım hatlarının yaygınlığının artırılması gerekliliğini vurgulamışlardır. Bütün bu önlemlerin yanı sıra büyük ailelerdeki ve sosyal çevredeki duyarlılığı artırıp sosyal destek mekanizmalarının geliştirilmesi gerekliliğinin de bir kez daha ön plana çıktığını vurgulamışlardır.

Leslie ve Wilson (2020) ABD'nin 14 metropol kentinde COVID-19 pandemisinin başladığ polise yapılan şiddet çağrılarında $\% 7.5^{\prime}$ lik bir artış tespit etmişlerdir. Devlet tarafinda resmi olarak verilen karantina ve kapanma kararları açıklanmadan önce başlayan bu şiddet sarmalı herhangi bir sosyodemografik değişkenle bağlı olmadığı ve aile içi özellikle eşe yönelik şiddetin daha önce hiç şiddet geçmişi olmayan bireyler arasında daha sık görüldüğünü tespit etmişlerdir.

Mazza, Marano, Lai, Janiri, ve Sani, (2020) PubMed/Medline, Scopus ve Embase gibi veri tabanlarını taramışlar ve elde ettikleri bulgular sonucunda COVID19 pandemisinin bireyleri görünmez ve karanlık bir düşmanla baş başa bırakarak onların kuşaklar arasında iletilen travma ve şiddet aktarımlarının yaşadıkları hayal kırıklıkları ve ajitasyonla aile üyelerine yönelttiklerini ileri sürmüşlerdir.

Moreira ve Pinto de Costa (2020) COVID-19 pandemisi sırasında PubMed veri tabanını eş şiddeti ve risk faktörleri anahtar kelimeleri ile taramış ve pandemi sırasında yayımlanan yayınlar üzerinden COVID-19 pandemisi sırasında eş şiddetini artıran risk faktörlerini tespit etmeye çalışmışlardır. Yaptıkları alan yazın çalışmasında pandeminin eş şiddetini artıran ya da tetikleyen faktörlerini bireysel, ilişkisel ve toplumsal/ sosyal faktörler olarak belirlemişlerdir. Pandeminin eş şiddetinin artıran bireysel faktörler arasında demografik özellikler, daha önce şiddete maruz kalma öyküsünün bulunması ve kurban ve failin psikolojik özelliklerinin ön plana çıktığı yapılan araştırmalarca tespit edilmiştir. İlişkisel faktörler arasında yüksek psiko-sosyal krizlere sahip olan çiftlerin daha çok risk altında oldukları bulunmuştur. Toplumsal/sosyal faktör arasında ise şiddet düzeyi yüksek ve sosyal olanakların kısıtlılığının yanı sıra sosyal olanaklara ulaşmaktaki güçlüklerin eş şiddetini artıran en önemli faktör olduğu tespit edilmiştir. Çünkü araştırmacılar bu gibi sosyal bağların güçlü olmadığı ve cinsiyet eşitsizliğinin var olduğu bu gibi topluluklarda şiddetin meşrulaştırıldı ${ }_{1}$ ve normalleştirildiği yorumunu yapmışlardır. Araştırmacılar COVID-19 pandemisinin eş şiddetini riskini artıran en önemli bileșenlerin ise pandeminin yayılımını önlemek için alınan sosyal izolasyon önlemleri ve karantina süreçlerine ek olarak yaşanılan ekonomik kayıplar ve aile üyelerinin normalden daha fazla aynı evin içinde yaşamak zorunda olmaları eş şiddetinin sıklığını ve şiddetinin artırmıştır. $\mathrm{Bu}$ bileşenlerin yanı sıra kurbanların alınan önlemler doğrultusunda ( sokağa çıkma yasağı, karantina vb.) gerekli hizmetlere ve yardım kurum/kuruluşlarına erişimini de engellemiştir.

Matoori, Khurana, Balcom ve ark. (2020) COVID-19 pandemisi ile birlikte hastanelerin acil servislerine eş şiddeti olgularında önemli bir artış olduğunu kaydetmişlerdir. Yapılan çalışmalarda eş şiddeti kurbanlarının yüz, parmaklar ve üst gövdede bulunan kemiklerde kırık ve çatlakların yanı sıra yine aynı bölgelerdeki yırtık, kesik, sıyrık ve morarmaların en yaygın türleri olduğunu fakat bu belirtilerin aynı zamanda kolaylıkla rutin travma olarak da algılanabileceklerini vurgulamışlardır. $\mathrm{Bu}$ dönemde özellikle bu gibi durumlarda muayene eden radyologların eş şiddeti konusunda daha dikkatli olmaları öncelikle olgu ve daha sonra da sevk eden doktor ile görüşme yaparak olgunun gerekirse devlet koruması altına alınmasını sağlamalarını önermistir.

Sharma ve Borah (2020) COVID-19 sırasında aile içi şiddet başvurularındaki artışı incelemek için yardım veren kuruluşlardaki istatistiki bilgilere ulaşmıştır. Ulaşılan bu veriler sonucunda ise COVID-19 sırasinda alınan önlemlerin aile içi şiddetin sadece sıklığını değil şiddetinin de arttığını tespit etmişlerdir. İşten çıkarılmalar, gelir kaybı, uzun süreli evde kalma zorunluluğu, ev içindeki alışkanlıkların değişmesi gibi etkenlerin aile içindeki şiddeti arttırdığı ve sonuç olarak da COVID-19 pandemisinin yeni bir sosyal ve ekonomik krize yol açtığını belirtmişlerdir. 
Bright, Burton ve Kosky (2020), COVID-19 ile birlikte "evde kal, hayat kurtar" yaklaşımının pandemiyi önlemede önemli olduğunu belirtirken, diğer bir halk sorunu olan aile içi şiddeti nasıl etkilediğine dair Amerika Birleşik Devletleri'nin kapanma sonrasındaki ilk 6 hafta içerisinde yayınlanan 300 haberin içerik analizini yapmışlardır. Araştırma devam etmekle birlikte ön verilerini sunarak, aile içi şiddetin sosyal izolasyon ve kapanma ile yaşanan strese bağl1 olarak arttığ belirtilmiştir. Yayınlanan haberler ile alan yazının kesiştiği önemli noktalar arasında medyanın aile içi şiddete yönelik ilgisinin arttığı, sosyal ve ekonomik güvenliğin teşviki ve önleme ile müdahalede finansal destek sağlanması yer almaktadır. Ayrıca kurbanlara sunulan yardım hizmetlerinin COVID-19 öncesindeki gibi var olduğunu ve ulaşımı kolaylaştırmanın gerekliliğine vurgu yapılmıştır.

Hamadani ve arkadaşları (2020) COVID-19 kapanması sonrası Bangladeş kırsalında yaşayan kadınlar ve aileleri üzerindeki etkisini belirlemeyi hedeflemişlerdir. Bangladeş kırsalındaki Rupganj Upazila'daki ailelerden toplanan gelir, gıda güvenliği ve ruh sağlığına ilişkin verileri karşılaştırmak için kesitsel bir çalışma yapmışlardır. Buna ek olarak COVID-19 pandemisi kapanma sonrası kadınların eş şiddetine maruz kalma durumları da incelenmiştir. 19 Mayıs - 18 Haziran 2020 tarihleri arasında 2424'ü onamlı 3016 çocuğun anne rastgele seçilip araştırma dâhil edilmişlerdir. Çalışma sonuçlarına göre eşleriyle birlikte yaşayan 2174 kadın, kapanma sırasında eş şiddetine maruz kalmıştır. Buna ek olarak kapanma sonrasında duygusal şiddettin \%68.4, fiziksel şiddettin $\% 56$ ve cinsel şiddettin ise $\% 50.8$ arttığ 1 bildirilmiştir.

Arenas-Arroyo, Fernandez-Kranz ve Nollenberger (2021) zorla birlikte yaşama ve ekonomik stresin eş şiddeti üzerindeki etkisini belirlemeye yönelik yaptıkları çalışmada, çevrim içi anket kullanılarak İspanya'daki toplam 13786 kadına ulaşmışlardır. Araştırmacılar, COVID-19 salgınının bir sonucu olarak, İspanya'daki 3 aylık kapanma sırasında eş şiddeti insidansının \% 23,38 arttığını belirtmektedirler. Eş şiddetinin iki bağımsız faktör ile arttığını ifade etmektedirler. Bunlardan birincisi kapanma diğeri ise ekonomik strestir. Buna ek olarak zorla yaşamanın psikolojik şiddeti beraberinde getirdiğini bununla birlikte, psikolojik şiddetin polise bildirilme oranını düşürdüğünü aktarmışlardır. Ayrıca araştırmacılar kapanmanın bitmesi ile şiddetin gözlenme oranında düşüşün beklenmediğini belirterek önlem alınmasını önermişlerdir.

Vieroa, Barbarab, Montiscia, Kustermannc ve Cattaneo (2020) kadına yönelik şiddet ve COVID-19 salgını arasındaki ilişki hakkındaki alanyazının hızlı ve eleştirel bir incelemesini yapmayı amaçlamışladır. Tarama işlemi sonrasında toplam 42 makaleyi incelemişlerdir. Salgını kontrol altına almak için yapılan evde kal politikalarının kadına yönelik şiddeti artırdığ 1 bildirilmiştir. Araştırmacılar Birleşmiş Milletlerin adlandırdığı şekliyle "salgın içinde bir gölge salgın" yaratıldığını ifade etmişlerdir. Buna rağmen COVID-19 pandemisi ile kadına yönelik şiddet arasındaki ilişkiyi çalışan araştırmaların oldukça kısıtlı olduğunu aktarmışlardır. Makalelerin ağırlıklı olarak editöre mektup ve anekdot niteliğinde olduğu da eklenmiştir. Araştırmacılar şiddet ile COVID-19 salgınına yönelik araştırmalar yapılmasını önermişlerdir.

\section{Tartışma}

Kadına yönelik eş şiddetinin COVID-19 Pandemisi özelinde kriz durumlarındaki görünürlüğünün kapsamlı incelenmesi alana önemli bir veri kaynağ oluşturmaktadır. İncelenen çalışmalarda kadınların aile içi şiddete maruz kalma oranları COVID-19 pandemisi ile arttığı görülmektedir. Acil kriz durumlarının eş şiddetinde artış meydana getirdiği geçmiş yıllardaki araştırmalarla ortaya konmuştur (Boserup, McKenney, \& Elkbuli, 2020). COVID-19 Pandemisi ile ülkeler genel kapanma ve salgını kontrol altına almaya yönelik "evde kal” kampanyaları düzenlemiş̧lerdir. Bu kampanyaların temel odak noktasi sosyal mesafe ve izolasyonu sağlamaktır. Dünyayı etkileyen COVID-19 Pandemisi için alınan önlemler aile içi şiddet salgınının ikincil bir salgın olarak gözlenmesinde önemli bir rol oynamıştır. Alan yazın incelendiğinde ampirik çalışmaların oldukça sınırlı olduğu gözlenmiştir. Etopya'da yapılan bir araştırmada COVID-19 Pandemisi sırasında kadınların \%13'ünün psikolojik şiddete maruz kaldıkları ve görücü usulü evliliklerde şiddet riskinin arttığı belirtilmektedir. Bir başka nicel araştırmada Nepal'de eş şiddetinin pandemi sürecinde $\% 18$ oranında arttı̆̆ını bildirmiştir (Ghimire ve diğ., 2020). Amerika'da ise eş şiddetinin \%5.3 oranında arttığı belirtilmektedir (Hsu ve Henke, 2020). Bangladeş'te COVID-19 pandemisinde \%68.4 duygusal, \%56 fiziksel, \%50 cinsel şiddetin arttı̆̆ bildirilirken (Hamadani ve diğ., 2020) İspanya'da eş şiddeti genel olarak ele alınmış ve artışın \%23 olduğu belirtilmiştir (Arenas-Arroyo, Fernandez-Kranz ve Nollenberger, 2021). Kültürel farklar eş şiddetinin gözlenme sıklığında farklılık ortaya çıkarmaktadır. COVID-19 Pandemisi ile gelen kapanma eş şiddeti mağdurlarının yardım almasını engellemektedir (Altın, 2021). Kadına yönelik şiddetin kültürel etmenlerden etkilendiği bildirilmekle birlikte yaşanılan sosyal mesafe ve ekonomik stresin eş şiddetinin gözlenmesindeki en önemli faktörler olduğu gözlenmiştir (Bright, Burton ve Kosky, 2020). İncelenen araştırmalarda ekonomik stresin eş şiddetini etkilediğine dair bulguların (Sharma ve Borah, 2020) yanı sıra Peru'da yapılan bir çalışmada sosyoekonomik düzeyin görülen eş şiddeti açısından anlamlı bir farklılık göstermediğini; sosyoekonomik düzeye bakılmaksınız şiddet çağrılarının bir yıl önceye oranla \%48 arttığı bildirilmiştir (Agüero, 2020). Benzer şekilde ABD'de polise yapılan şiddet başvurularında artış olmuşken, yapılan başvurularda sosyodemografik değişkenlerin anlamlı bir farklılık ortaya koymadığ 1 belirtilmiştir (Leslie ve Wilson, 2020). Ataerkil yapılarda kadın cinayetleri diğer toplumlara göre daha s1k gözlenmektedir. Aile içi şiddetten korunma hizmetleri bu ülkelerde olsa da hizmete ulaşım, kültürel özelliklerden dolayı mümkün olmamaktadır. Pakistan'da sadece Mart 2020'de 399 kadın eşleri tarafından öldürülmesine rağmen polise 25 aile içi şiddet başvurusu yapıllmıştır (Baig, Ali ve Tunio, 2020). Türkiye'de 2020 yılı içerisinde 284 kadın öldürülmüş, bu kadınların $\% 65$ 'i ise eş veya sevgilisi tarafından öldürülmüştür (Kepenek, 2021). Farklı ülkelerde eş şiddetini etkileyen etmenler farklılık göstermiştir ancak tüm çalışmalardaki ortak faktörün COVID-19 Pandemisi olduğu gözlenmiştir. Miller ve McCaw (2019) eş şiddetinin farklı faktörlerin birlikte etkileşimi ile ortaya çıktığını öne sürmektedirler. 


\section{Sonuç}

İncelenen araştırmalarda kapanma sonrası aile içi şiddete artı̧̧ olduğu belirlenmiş̧ir. Ülkeler açısından değerlendirildiğinde artış oranlarında farklılıklar bulunmaktadır. $\mathrm{Bu}$ da kültürel etmenlerin kadınlığa yönelik algısı ile açıklanabilmektedir. Ev içi şiddet olgularının ev içinde kalmasında yönelik tutumun ağırlıkta olduğu ülkelerde oran artışları ile ilgili nesnel bilgiler elde etmek oldukça güç olmaktadır. Pakistan'da yapılan araştırma buna örnek olarak verilebilir. Kadın kocasına aittir ve kocanın şiddet eylemleri meşru görülmektedir. Toplumunun genel tutumu kadının eş şiddetine maruz kalmasında önemli bir etkendir. Pandemi gibi toplumsal kriz durumlarında ise bu davranışlar daha da s1k gözlenmektedir. COVID-19 Pandemisinde evde kalma, sosyal mesafe ve izolasyon hem eş şiddetinin ev içerisinde artmasına neden olmakta hem de mağdurun yardım almasına engel olabilmektedir. $\mathrm{Bu}$ doğrultuda kadınların eş şiddetine maruz kalmada sıklığının arttığı ve yardım alamadıkları gözlenmiştir. İncelenen araştırmalarda eş şiddeti ikinci bir salgın olarak nitelendirilmektedir. Alan yazındaki çalışmalar oldukça sınırlıdır. Özellikle kapanmaya bağlı olarak şiddet mağduru kadınlara ulaşmada da zorluklar yaşanmaktadır. Kadınların eş şiddetinden korunmaları için oluşturulacak politikalarda kadınların yardım hizmetlerine ulaşabilmesi öncelikli konu olmalıdır. Ülkelerin ilk odak noktası
COVID-19 olsa da pandemi süreci ve sonrasında ortaya çıkabilecek psikososyal sorunların belirlenmesi gerekmektedir. Bu doğrultuda hazırlık yapılması ve kriz merkezlerinin oluşturulması önerilmektedir. Araştırmacıların önleme ve müdahale programları geliştirmeleri, eş şiddeti ile mücadelede önemli bir katkı sağlayacağ d düşünülmektedir.

\section{Beyannameler}

Etik Onay ve Katılma İzni

Uygulanamaz.

Yayın İzni

Uygulanamaz.

Veri ve Materyallerin Mevcudiyeti

Uygulanamaz.

Çıkar Çatışması

Yazarlar çıkar çatışması olmadığını beyan eder.

Finansman

Uygulanamaz.

Yazar Katkıları

$\mathrm{ZO}, \mathrm{CD}, \mathrm{GBA}$ çalış̧manın tasarımını oluşturmuştur. ZO, CD, GBA veri toplama aşamasını yürütmüștür. $\mathrm{ZO}, \mathrm{CD}, \mathrm{GBA}$ verileri analiz etmiştir. $\mathrm{ZO}, \mathrm{CD}$, GBA makalenin taslağını oluşturmuş ve kritik revizyonunu üstlenmiştir. $\mathrm{ZO}, \mathrm{CD}$, GBA, çalışmanın teknik ve materyal desteğini sağlamıștır. Tüm yazarlar makalenin son halini okumuş ve onaylamıştır.

\section{Kaynaklar}

Agüero J. M. (2021). COVID-19 and the rise of intimate partner violence. World Development, 137, 105217. https://doi.org/10.1016/j.worlddev.2020.105217

Altın, G. (2021). COVID-19 Pandemisi Bağlamında kadına karșı şiddete ilişkin bir değerlendirme. Toplum ve Sosyal Hizmet, 32(1), 211-225. https://doi.org/10.33417/tsh.760243

Arenas-Arroyo, E., Fernandez-Kranz, D., \& Nollenberger, N. (2021). Intimate partner violence under forced cohabitation and economic stress: Evidence from the COVID-19 pandemic. Journal of Public Economics, 194, 104350. https://doi.org/10.1016/j.jpubeco.2020.104350

Baig, M. A. M., Ali, S., \& Tunio, N. A. (2020). Domestic violence amid COVID-19 Pandemic: Pakistan's perspective. Asia Pacific Journal of Public Health, 32(8), 525-526. https://doi.org/10.1177/1010539520962965

Barnawi, F. H. (2017). Prevalence and risk factors of domestic violence against women attending a primary care center in Riyadh, Saudi Arabia. Journal of Interpersonal Violence, 32(8), 1171-1186. https://doi.org/10.1177/0886260515587669

Boserup, B., McKenney, M., \& Elkbuli, A. (2020). Alarming trends in US domestic violence during the COVID-19 pandemic. The American Journal of Emergency Medicine, 38(12), 27532755. https://doi.org/10.1016/j.ajem.2020.04.077

Bradbury- Jones, C., \& Isham, L. (2020). The pandemic paradox: The consequences of COVID- 19 on domestic violence. Journal of Clinical Nursing, 29, 2047-2049. https://doi.org/10.1111/jocn.15296

Bradley, N. L., DiPasquale, A. M., Dillabough, K., \& Schneider, P. S. (2020). Health care practitioners' responsibility to address intimate partner violence related to the COVID-19 pandemic. CMAJ, 192(22), E609-E610. https://doi.org/10.1503/cmaj.200634

Bright, C. F., Burton, C., \& Kosky, M. (2020). Considerations of the impacts of COVID-19 on domestic violence in the United
States. Social Sciences \& Humanities Open, 2(1), 100069. https://doi.org/10.1016/j.ssaho.2020.100069

Brown, C. S., Ravallion, M., \& Van de Walle, D. (2020). Can the world's poor protect themselves from the new coronavirus? (No. w27200). National Bureau of Economic Research. Cambridge May 2020, working paper, Erişim 02 Şubat 2021.

Buttell, F., \& Ferreira, R. J. (2020). The hidden disaster of COVID-19: Intimate partner violence. Psychological Trauma: Theory, Research, Practice, and Policy, 12(S1), S197. http://dx.doi.org/10.1037/tra0000646

El- Serag, R., \& Thurston, R. C. (2020). Matters of the heart and mind: interpersonal violence and cardiovascular disease in women. Journal of the American Heart Association, 9(4), 1-4. https://doi.org/10.1161/JAHA.120.015479

Ergönen, A. T., Biçen, E., \& Ersoy, G. (2020). COVID-19 Salgınında Ev İçi Şiddet. The Bulletin of Legal Medicine,

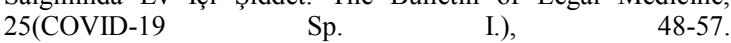
https://doi.org/10.17986/blm.2020.v25i.1408

Ertan, D., El-Hage, W., Thierrée, S., Javelot, H., \& Hingray, C. (2020). COVID-19: urgency for distancing from domestic violence. European Journal of Psychotraumatology, 11(1), 1800245. https://doi.org/10.1080/20008198.2020.1800245

Gebrewahd, G.T., Gebremeskel, G.G. \& Tadesse, D.B.(2020). Intimate partner violence against reproductive age women during COVID-19 pandemic in northern Ethiopia 2020: a communitybased cross-sectional study. Reprod Health 17, 152. https://doi.org/10.1186/s12978-020-01002-w

Ghimire, C., Acharya, S., Shrestha, C., KC, P., Singh, S., \& Sharma, P. (2020). Interpersonal Violence during the COVID-19 Lockdown Period in Nepal: A Descriptive Cross-sectional Study. JNMA: Journal of the Nepal Medical Association, 58(230), 751-757. https://doi.org/10.31729/jnma.5499

Gulati, G., \& Kelly, B. D. (2020). Domestic violence against women and the COVID-19 pandemic: What is the role of 
psychiatry?. International Journal of Law and Psychiatry, 71, 101594. https://doi.org/10.1016/j.ijlp.2020.101594

Hale, T., Webster, S., Petherick, A., Phillips, T. \& Kira, B. (2020). Oxford COVID-19 Government Response Tracker. https://apo.org.au/node/303043. Erişim tarihi: 23 Ocak 2021.

Hall, B.J. \& Tucker, J.D. (2020). Surviving in place: The coronavirus domestic violence syndemic. Asian Journal of Psychiatry, 53, 102179. https://doi.org/10.1016/j.ajp.2020.102179

Hamadani, J. D., Hasan, M. I., Baldi, A. J., Hossain, S. J., Shiraji, S., Bhuiyan, M. S. A., ., Fisher, J., Tofail, F., Tipu, S.M.M.U., Grantham-McGregor, S., Biggs, B.A., Braat, S. \& Pasricha, S. R. (2020). Immediate impact of stay-at-home orders to control COVID-19 transmission on socioeconomic conditions, food insecurity, mental health, and intimate partner violence in Bangladeshi women and their families: an interrupted time series. The Lancet Global Health, 8(11), e1380-e1389. https://doi.org/10.1016/S2214-109X(20)30366-1

Hsu, L.C., Henke, A.(2020). COVID-19, staying at home, and domestic violence. Rev Econ Household. https://doi.org/10.1007/s11150-020-09526-7

Ingram, K. M., Espelage, D. L., Davis, J. P., \& Merrin, G. J. (2020). Family violence, sibling, and peer aggression during adolescence: associations with behavioral health outcomes. Frontiers in Psychiatry, 11, 26. https://doi.org/10.3389/fpsyt.2020.00026

John, N., Casey, S. E., Carino, G., \& McGovern, T. (2020). Lessons Never Learned: Crisis and gender-based violence. Developing World Bioethics, 20(2). https://doi.org/10.1111/dewb.12261

Karaçam, Z . (2013). Sistematik Derleme Metodolojisi: Sistematik Derleme Hazırlamak İçin Bir Rehber . Dokuz Eylül Üniversitesi Hemşirelik Fakültesi Elektronik Dergisi , 6 (1) , 2633 . Retrieved from https://dergipark.org.tr/tr/pub/deuhfed/issue/46815/587078

Kepenek, E.(2021). Bianet Bağımsız İletişim Ağı. 24 Kasım 2020. 25 Kasım Kadına Yönelik Şiddetle Mücadele Günü: Erkekler 327 günde 253 kadını öldürdü, 715 kadını yaraladı. https://m.bianet.org/bianet/toplumsal-cinsiyet/234827-erkekler327-gunde-253-kadini-oldurdu-715-kadini-yaraladi: Erişim tarihi: 07 Şubat 2021.

Leslie, E., \& Wilson, R. (2020). Sheltering in place and domestic violence: Evidence from calls for service during COVID-19. Journal of Public Economics, 189, 104241. https://doi.org/10.1016/j.jpubeco.2020.104241

Matoori, S., Khurana, B., Balcom, M.C. et al.(2020). Addressing intimate partner violence during the COVID-19 pandemic and beyond: how radiologists can make a difference. Eur Radiol. https://doi.org/10.1007/s00330-020-07332-4

Mazza, M., Marano, G., Lai, C., Janiri, L., \& Sani, G. (2020). Danger in danger: Interpersonal violence during COVID-19 quarantine. Psychiatry Research, 289, 113046. https://doi.org/10.1016/j.psychres.2020.113046
Miller, E., \& McCaw, B. (2019). Intimate partner violence. New England Journal of Medicine, 380(9), 850-857. https://doi.org/10.1056/NEJMra1807166

Mohler, G., Bertozzi, A.L., Carter, J., Short, M.B., Sledge, D., Tita, G.E., Uchida, C. D. \& Brantingham, J.P. (2020). Impact of social distancing during COVID-19 pandemic on crime in Los Angeles and Indianapolis. Journal of Criminal Justice, 68, 101692, 1-7. https://doi.org/10.1016/j.jcrimjus.2020.101692

Moreira, D. N., \& Pinto da Costa, M. (2020). The impact of the COVID-19 pandemic in the precipitation of intimate partner violence. International Journal of Law and Psychiatry, 71. https://doi.org/10.1016/j.ijlp.2020.101606

Peterman, A., Potts, A., O'Donnell, M., Thompson, K., Shah, N., Oertelt-Prigione, S., \& Van Gelder, N. (2020). Pandemics and violence against women and children (Vol. 528). Washington, DC: Center for Global Development. https://www.cgdev.org/publication/ pandemics-and-violenceagainst-women-and-children, Erişim tarihi: 8 Şubat 2021

Roesch, E., Amin, A., Gupta, J., \& García-Moreno, C. (2020). Violence against women during COVID-19 pandemic restrictions. BMJ: British Medical Journal,369, 1-2. https://doi.org/10.1136/bmj.m1712

Sánchez, O. R., Vale, D. B., Rodrigues, L., \& Surita, F. G. (2020). Violence against women during the COVID- 19 pandemic: An integrative review. International Journal of Gynecology \& Obstetrics, 151(2), 180-187. https://doi.org/10.1002/ijgo.13365

Sharma, A., Borah, S.B.(2020). COVID-19 and Domestic Violence: an Indirect Path to Social and Economic Crisis. J Fam Viol . https://doi.org/10.1007/s10896-020-00188-8

Telles, L. E., Valenca, A. M., Barros, A. J., \& da Silva, A. G. (2020). Domestic violence in the COVID-19 pandemic: a forensic psychiatric perspective. Brazilian Journal of Psychiatry, (AHEAD). https://doi.org/10.1590/1516-4446-2020-1060

Toprak Ergönen, A., Biçen, E., Ersoy G. (2020). COVID-19 Salgınında Ev İçi Şiddet. Bull Leg Med. 30 Mayıs 2020;25(Özel Say1 ):48-57.

Van Gelder, N., Peterman, A., Potts, A., O'Donnell, M., Thompson, K., Shah, N., \& Oertelt-Prigione, S. (2020). COVID19: Reducing the risk of infection might increase the risk of intimate partner violence. EClinicalMedicine, 21, 100348. https://doi.org/10.1016/j.eclinm.2020.100348

Viero, A., Barbara, G., Montisci, M., Kustermann, K., \& Cattaneo, C. (2020). Violence against women in the COVID-19 pandemic: a review of the literature and a call for shared strategies to tackle health and social emergencies. Forensic Science International, 110650. http://dx.doi.org/10.1016/j.forsciint.2020.110650

World Health Organization. Director- General's opening remarks at the media briefing on COVID- 19 [WHO website]. 2020. https://www. who.int $/ \mathrm{dg} / \mathrm{speeches/detail/who-} \mathrm{director-}$ general- s- opening- remar ks- at- the- media- briefing- onCOVID- 19- 11- march- 2020. Erișim tarihi: 22 Ocak 2021. 